\title{
Faktor Pendukung dan Penghambat Pembinaan Kesejahteraan Keluarga (PKK) dalam Meningkatkan Keterampilan Warga Negara Melalui Program Pokok PKK
}

\author{
Ludovikus Bomans Wadu ${ }^{1}$, Iskandar Ladamay ${ }^{2}$, Maria Yosefina Dadi ${ }^{3}$ \\ Universitas Kanjuruhan Malang \\ $\underline{\text { ludovikusbomanwadu@unikama.ac.id }}^{1}$ \\ mariayosefina3005@gmail.com ${ }^{3}$
}

\begin{abstract}
ABSTRAK
Artikel ini memberikan gambaran faktor pendukung dan penghambat yang dialami Tim Penggerak Pembinaan Kesejahteraan Keluarga (TP. PKK) dalam meningkatkan keterampilan warga negara melalui program pokok PKK. Penelitian ini dilatarbelakangi oleh adanya kegiatan TP.PKK yang melibatkan warga negara untuk menjadikan mereka warga negara yang baik dalam konteks citizenship education. Penelitian ini menggunakan pendekatan kualitatif dengan jenis penelitian studi kasus. Hasil penelitian menunjukan bahwa semangat dan kesadaran masyarakat sangat baik dalam setiap pelaksanaan kegiatan. Selain itu Anggaran Dana Desa setidaknya mendukung pelaksanaan program pendidikan dan keterampilan. Sedangkan faktor penghambat yang ditemukan adalah kendala pemasaran dan minimya dana yang dimiliki masyarakat untuk mengembangkan keterampilan yang diajarkan TP.PKK.
\end{abstract}

Kata Kunci : PKK, Keterampilan, Keterampilan Warga Negara

\section{ABSTRACT}

This article provides an overview of the supporting factors and obstacles experienced by the Tim Penggerak Pembinaan Kesejahteraan Keluarga (TP PKK) in improving the civic skills through the PKK main program. This research is motivated by the existence of TP.PKK activities involving citizens to prepare them as a good citizen in the civic education context. This research uses qualitative approach with case study research method. The results show the passion, and community awareness is meritorious in every activity. The marketing objectives and the limited funds are found as obstacles factors for the community to develop the skills that taught by TP.PKK.

Keywords: PKK, Skills, Civic Skills

\section{PENDAHULUAN}

Perempuan merupakan bagian dari warga negara yang perlu diberdayakan oleh pemerintah untuk mewujudkan tujuan negara guna mencapai millenium development goals. Pemberdayaan perempuan adalah upaya peningkatan kemampuan wanita dalam mengembangkan kapasitas dan keterampilannya untuk meraih akses dan penguasaan seperti: pengambilan keputusan, sumber-sumber, dan struktur atau jalur yang menunjang (Aritonang dalam Trisnawati dan Jatiningsih, 2017). Pemberdayaan yang dilakukan ini, diharapakan dapat memberikan dampak yang baik bagi perempuan sebagai bagian dari warga negara. Dengan adanya pemberdayaan perempuan, diharapkan agar perempuan sebagai warga negara yang baik memiliki kemandirian sehingga 
JIP, Vol.8, No. 1, Edisi Januari 2018, Hal: 62-71

Ludovikus Bomans Wadu, Iskandar Ladamay, Maria Yosefina Dadi

dapat meningkatkan kemampuannya dalam memperbaiki kualitas kehidupan mereka serta dapat berpartisipasi mewujudkan pembagunan nasional.

Banyak upaya yang telah dilakukan oleh pemerintah untuk memberdayakan pemerintah. Dalam bidang organisasi pemerintah telah melegalkan beberapa organisasi kemasyarakatan yang dikhususkan bagi wanita salah satunya adalah PKK. Menurut Arisandi (2015:1887) menyatakan bahwa "PKK merupakan organisasi masyarakat yang diperuntukkan bagi para wanita agar dapat mengembangkan dirinya didalam masyarakat". Melalui pendapat ini disimpulkan bahwa PKK merupakan organisasi yang khusus dibentuk untuk memberdayakan wanita agar dapat mengembangkan diri didalam lingkungan masyarakat.

Pemberdayaan yang dilakukan oleh PKK melalui program pokok PKK, salah satu program pokok PKK adalah pendidikan dan keterampilan. Program Pendidikan dan Keterampilan dalam organisasi PKK menurut Jovani (2016:154) menyatakan bahwa "PKK melaksanakan program keaksaraan fungsional, pelatihan yang dilakukan untuk membuat kerajinan tangan, produk makanan dan minuman yang hasilnya dapat dijual untuk meningkatkan penghasilan pendapatan keluarga". Pada program pendidikan dan keterampilan dalam linkungan masyarakat, wanita diajak untuk melakukan berbagai kegiatan kerajinan tangan melalui pelatihan keterampilan. Pelatihan keterampilan yang dilaksanakan bertujuan untuk meningkatkan perekonomian masyarakat.

Pada penelitian ini lebih difokuskan untuk melihat faktor pendukung dan penghambat yang dialami PKK dalam melaksanakan kegiatan keterampilan. Menurut Nasution dalam Riana dkk, (2014:853) menyatakan bahwa "keterampilan adalah kemampuan untuk mengerjakan atau melaksanakan sesuatu dengan baik". Menurut pendapat diatas dapat disimpulkan bahwa keterampilan merupakan kesanggupan manusia untuk menghasilkan sesuatu yang berguna. Dalam pelaksanaan pelatihan keterampilan yang dilakukan oleh PKK tentu ada faktor pendukung dan faktor penghambat yang akan dibahas dalam artikel ini.

Berkaitan dengan pendidikan kewarganegaraan penulis ingin menggambarkan adanya faktor pendukung dan penghambat PKK melakukan kegiatan pelatihan keterampilan untuk meningkatkan keterampilan warga negara dalam ranah pendidikan kewarganegaraan diluar sekolah (citizenship education) untuk menyelesikan permasalahan atau isu 
JIP, Vol.8, No. 1, Edisi Januari 2018, Hal: 62-71

Ludovikus Bomans Wadu, Iskandar Ladamay, Maria Yosefina Dadi

yang berasal dari dalam negara. Menurut Suryadi dan Somardi dalam Setiawan (2016:64), keterampilan kewarganegaraan (civic skills) "merupakan keterampilan yang dikembangkan dari pengetahuan kewarganegaraan, agar pengetahuan yang diperoleh menjadi sesuatu yang bermakna, karena dapat dimanfaatkan dalam menghadapi masalah-masalah kehidupan berbangsa dan bernegara”. Masalah masalah yang dimaksudkan disini adalah masalah yang ada didalam lingkungan masyarakat yang dialami oleh wanita seperti masalah kemiskinan, kesenjangan ketenagakerjaan, dan lain sebagainya. Pemberdayaan yang dilakukan PKK sebagai mitra kerja pemerintah diharapkan dapat memberikan manfaat untuk perempuan.

\section{METODE}

Pendekatan yang digunakan dalam penelitian ini adalah pendekatan kualitatif.

Dalam bukunya Moleong (2016:6) menyatakan bahwa :

Penelitian kualitatif adalah penelitian yang bermaksud untuk memahami fenomena tentang apa yang dialami oleh subjek penelitian misalnya perilaku, persepsi, motivasi, tindakan,dll., secara holistik dan dengan cara deskripsi dalam bentuk kata kata dan bahasa pada suatu konteks khusus yang alamiah dan dengan memanfaatkan berbagai metode alamiah.

Jenis penelitian yang digunakan dalam penelitian ini adalah studi kasus. Menurut Stake dalam bukunya Creswell (2016:19) menyatakan bahwa "studi kasus merupakan rancangan penelitian yang dikemukakan dibanyak bidang, khususnya evaluasi, dimana peneliti mengembangkan analisis mendalam atas suatu kasus, sering kali program peristiwa aktivitas, proses, atau satu individu atau lebih".

Sumber data dalam penelitian ini terdiri dari dua yaitu data utama dan data tambahan. Menurut Lofland dan Loflan dalam bukunya Moleong (2016:157) menyatakan bahwa "sumber data utama dalam penelitian kualitatif ialah kata - kata dan tindakan selebihnya adalah data tambahan seperti dokumen dan lain lain". Sumber data utama atau data primer dari penelitian ini berupa wawancara yang dilakukan dengan pihak TP.PKK serta masyarakat Desa Tlogorejo dan observasi kegiatan pelatihan keterampilan TP.PKK Desa Tlogorejo. Sumber data tambahan dalam penelitian ini berupa dokumentasi presensi kehadiran dan alokasi Anggaran Dana Desa (ADD) untuk pelaksanaan kegiatan PKK.

Teknik penelitian atau prosedur pengumpulan data yang digunakan dalam penelitan ini terdiri atas wawancara, 
JIP, Vol.8, No. 1, Edisi Januari 2018, Hal: 62-71

Ludovikus Bomans Wadu, Iskandar Ladamay, Maria Yosefina Dadi

observasi dan dokumentasi. Dalam bukunya Creswell (2016) menyatakan bahwa "prosedur pengumpulan data terdiri dari wawancara, observasi dan dokumentasi". Prosedur pengumpulan data berupa wawancara dan observasi merupakan bagian dari data primer yang telah dijelaskan sebelumnya, sedangkan dokumentasi merupakan bagian dari sumber data sekunder yang telah dijelaskan sebelumnya. Prosedur pengumpulan data yang dilakukan dalam penelitian ini bertujuan untuk mencapai tujuan dilaksanakannya penelitian.

\section{HASIL DAN PEMBAHASAN}

Hasil

\begin{tabular}{lrrr}
\multicolumn{2}{c}{ Berdasarkan } & hasil & wawancara \\
disimpulkan & bahwa & faktor & pendukung \\
TP.PKK & dalam & meningkatkan
\end{tabular}
keterampilan warga negara yang pertama adalah semangat dari masyarakat itu sendiri, kedua alokasi dana ADD yang mendukung untuk pelaksanaan program pendidikan dan keterampilan, ketiga adanya kesadaran dari masyarakat yang menyatakan tanggapan bahwa kegiatan ini sangat baik dan bagus, keempat ketersediaan tempat pelaksanaan kegiatan, dan kelima dukungan dari perangkat desa. Faktor penghambat TP.PKK dalam meningkatkan keterampilan warga negara adalah kesibukan dari masyarakat itu sendiri, pemasaran dari hasil kegiatan yang belum maksimal, dan keterbatasan dana yang dialami masyarakat untuk mengembangkan hal yang telah diajarkan oleh TP.PKK. Faktor pendukung yang telah dijabarkan diatas menjadi modal utama TP.PKK untuk meningkatkan keterampilan warga negara dalam ranah pendidikan kewarganegaraan diluar sekolah. Sedangkan faktor penghambat menjadi kendala PKK dalam memberdayakan wanita untuk meningkatkan keterampilan warga negara khususnya wanita.

Observasi dilakukan dalam pelaksanaan kegiatan ketererampilan. Kajian yang diobservasi diperoleh berdasarkan wawancara untuk dilihat kesesuaiannya. Berdasarkan hasil observasi yang dilakukan oleh peneliti pada saat dapat disimpulkan bahwa faktor pendukung kegiatan untuk meningkatkan keterampilan warga negara khususnya wanita adalah ketersediaan fasilitas kegiatan, fasilitas kegiatan ini diperoleh melalui alokasi dana dari ADD. Sedangkan faktor penghambat TP. PKK dalam meningkatkan keterampilan warga negara khususnya wanita adalah kehadiran dari masyarakat itu sendiri.

Dokumen yang diperoleh dalam penelitian ini adalah dokumen yang diperoleh berdasarkan hasil wawancara 
JIP, Vol.8, No. 1, Edisi Januari 2018, Hal: 62-71

Ludovikus Bomans Wadu, Iskandar Ladamay, Maria Yosefina Dadi

dan hasil observasi. Dokumen yang digunakan dalam penelitian ini digunakan untuk menunjang hasil observasi dan wawancara yang telah dilakukan.

Dokumentasi faktor pendukung berupa alokasi dana ADD diperoleh peneliti dari kantor desa Tlogorejo. Sedangkan dokumen faktor penghambat berupa kehadiran masyarakat dalam penelitian ini diperoleh dalam bentuk presensi yang diperoleh dari pihak TP.PKK desa Tlogorejo.

\section{Pembahasan}

Berdasarkan Peraturan Menteri

Dalam Negeri Republik Indonesia Nomor

1 Tahun 2013 tentang Pemberdayaan Masyarakat melalui Gerakan Pemberdayaan dan Kesejahteraan Keluarga Bab I Pasal 1 Ayat 10 yang yang berbunyi : "Tim Penggerak PKK untuk selanjutnya disingkat dengan TP PKK adalah fasilitator, perencana, pelaksana, pengendali dan penggerak pada masingmasing tingkat pemerintahan untuk terlaksananya program PKK yang merupakan mitra kerja pemerintah, dan organisasi kemasyarakatan/lembaga kemasyarakatan lainnya". Berdasarkan peraturan menteri diatas dapat disimpulkan bahwa PKK merupakan mitra kerja pemerintah yang berperan untuk memberdayakan masyarakat. Namun dalam menjalankan peran tersebut masih ada hal yan mendukung dan menghambat PKK untuk menjalankan peran tersebut. Hal ini sesuai dengan apa yang sudah ditemukan peneliti dilokasi penelitian.

Faktor Pendukung TP. PKK dalam meningkatkan keterampilan warga negara antaralain; Pertama, semangat dari masyarakat itu sendiri. Semangat ini dilihat pada saat peneliti melakukan observasi dan melalui keterangan dari informan dari hasil wawancara. Para wanita tetap antusias mengikuti kegiatan ini walaupun pada saat itu didesa cuacanya kurang bersahabat. Para wanita juga memiliki keluarga yang harus diurus dirumah tapi mereka tetap berusaha hadir demi mendapatkan pengetahuan keterampilan yang diajarkan oleh PKK.

Kedua, alokasi dana ADD. Pada saat peneliti melakukan observasi penggunaan dana alokasi ADD dapat dilihat dari ketersediaan perlengkapan untuk melakukan kegiatan keterampilan. Pembiyaan pelatihan ini ditanggung secara utuh oleh PKK melalui alokasi dana ADD. Alokasi dana ini disalurkan oleh desa melalui APBD untuk bidang pembinaan kemasyarakatan dan PKK merupakan salah satu dari tiga bidang pembinaan masyarakat yang mendapat dana ADD dari pemerintah.

Ketiga, adanya kesadaran dari masyarakat yang menyatakan tanggapan 
JIP, Vol.8, No. 1, Edisi Januari 2018, Hal: 62-71

Ludovikus Bomans Wadu, Iskandar Ladamay, Maria Yosefina Dadi

bahwa kegiatan ini sangat baik dan bagus. Kesadaran menjadi modal utama dalam pelaksanaan kegiatan ini. Masyarakat sadar bahwa kegiatan ini sangat bagus untuk masyarakat. Namun pelaksanaannya belum maksimal dikarenakan oleh kesibukan masyarakat itu sendiri.

Keempat, ketersediaan tempat pelaksanaan kegiatan. Hal ini menjadi faktor pendukung karena untuk pelaksanaan kegiatan ini baik dari PKK RT, RW maupun desa masyarakat ataupun dari pihak desa sendiri secara sukarela memeberikan tempat untuk melaksanakan kegiatan ini. Kegiatan ini dapat terlaksana karena ada tempat yang digunakan sebagai naungan untuk melakukan pelatihan keterampilan. Pada saat peneliti melakukan penelitian pelatihan keterampilan ini dilaksanakan kantor desa.

Kelima, dukungan dari perangkat desa. Dukungan ini terlihat pada saat peneliti melakukan obsevasi dilapangan. Dimana para perangkat desa juga ikut bersosialisasi dengan masyarakat untuk mengikuti kegiatan ini. Dukungan dari perangkat desa menjadi motivasi positif tersendiri untuk organisasi PKK karena ada yang mendukung TP.PKK untuk melaksanakan kegiatan ini.

Faktor pendukung TP.PKK dalam memberdayakan masyarakat juga didukung oleh hasil RAKERNAS PKK.
Berdasarkan keputusan ketua umum TP PKK Nomor : 01 / KEP / PKK PST / VII/2010 TENTANG RUMUSAN HASIL RAKERNAS VII PKK TAHUN 2010 menyatakan "bahwa dalam rangka meningkatkan kualitas Gerakan PKK dalam ikut serta melaksanakan pembangunan nasional, diperlukan pemantapan pengelolaan Gerakan PKK dengan memanfaatkan sumber daya yang lebih berdaya guna dan berhasil guna". Ini berarti, dalam menjalankan tugasnya PKK dapat memanfaatkan sumber daya agar hasil dari kegiatan PKK dapat berguna bagi pembangunan nasional. Pengelolaan yang dilakukan oleh PKK dilapangan penelitian baik dari sumber daya manusia maupun sumber daya alam telah dilaksanakan dalam menimplementasikannya PKK bekerjasama dengan seluruh komponen yang ada didesa.

Faktor Penghambat TP. PKK Dalam Meningkatkan Keterampilan Warga Negara diantaranya; Pertama, kesibukan dari masyarakat itu sendiri. Kesibukan ini dilihat melalui presensi dan wawancara yang dilakukan dengan masyarakat. Hal ini menjadi kendala utama bagi PKK untuk menjalankan program ini. Karena kehadiran masyarakat merupakan modal utama bagi terlaksananya program pokok 
JIP, Vol.8, No. 1, Edisi Januari 2018, Hal: 62-71

Ludovikus Bomans Wadu, Iskandar Ladamay, Maria Yosefina Dadi

PKK guna meningkatkan keterampilan warga negara.

Kedua, pemasaran dari hasil kegiatan yang belum maksimal. Hal ini menjadi kendala untuk PKK dalam mengembangkan berbagai keterampilan untuk meningkatkan keterampilan masyarakat. Pemasaran yang belum optimal menjadi pemicu kurangnya minat belajar dari masyarakat untuk memperoleh pengetahuan tentang keterampilan. Pemasaran dari hasil kegiatan yang belum maksimal juga mungkin mempengaruhi semangat kehadiran untuk mengikuti kegiatan pelatihan keterampilan.

Ketiga, keterbatasan dana yang dialami masyarakat untuk mengembangkan hal yang telah diajarkan oleh TP.PKK. Hal ini ditemukan oleh peneliti pada saat peneliti melakukan penelitian. Masyarakat memiliki harapan bahwa pemerintah sebaiknya memberi bantuan juga untuk mengembangkan keterampilan yang sudah diajarkan PKK. Keterbatasan dana dari pihak masyarakat mungkin juga yang menyebabkan rendahnya partisipasi masyarakat untuk mengikuti kegiatan pelatihan keterampilan ini.

Berdasarkan Keputusan Menteri

Dalam Negeri Dan Otonomi Daerah Republik Indonesia Nomor: 53 Tahun 2000 Tentang Gerakan Pemberdayaan Dan
Kesejahteraan Keluarga Bab II Tentang Tujuan Dan Sasaran Pasal 3 menyatakan bahwa:

Sasaran Gerakan PKK adalah keluarga di perdesaan dan perkotaan yang perlu ditingkatkan dan dikembangkan kemampuan dan kepribadian dalam bidang: (1) Mental spiritual, meliputi sikap dan perilaku sebagai insan hamba Tuhan, anggota masyarakat dan warga negara dinamis dan bermanfaat, berdasarkan Pancasila dan Undang-Undang Dasar 1945; (2) Fisik material, yang meliputi pangan, sandang, papan, kesehatan, kesempatan kerja yang layak serta lingkungan hidup yang lestari melalui peningkatan pendidikan, pengetahuan dan keterampilan.

Berdasarkan keputusan menteri diatas dapat disimpulkan bahwa pada umumnya sasaran dari gerakan PKK adalah untuk meningkatkan mental spritual dan fisik material masyarakat agar dapat hidup layak guna mewujudkan tujuan dari kegiatan PKK. Untuk mewujudkan tujuan dari sasaran gerakan PKK belum dapat dilaksanakan secara optimal. Hal ini dikarenakan masih adanya faktor penghambat yang muncul dalam pelaksanaannya.

Komponen keterampilan dalam Pendidikan Kewarganegaraan

(Winataputra dalam Adnan, 2005:72) 
JIP, Vol.8, No. 1, Edisi Januari 2018, Hal: 62-71

Ludovikus Bomans Wadu, Iskandar Ladamay, Maria Yosefina Dadi

terdiri atas "kemampuan keterampilan

intelektual, keterampilan sosial, keterampilan partisipatif'. Dalam keterampilan intelektual melibatkan kecapakan intelektual dari warga negara untuk mengolah persoalan dalam kehidupan bernegara, keterampilan sosial merupakan keterampilan yang mengarahkan masyarakat untuk menjalankan hak serta kewajiban dalam mendukung kehidupan pemerintahan dalam negara, keterampilan partisipatif adalah keterampilan yang berhubungan dengan partisipasi warga negara dalam kehidupan bernegara. Dalam hal ini PKK merupakan jembatan pelaksana pemenuhan komponen keterampilan yang dijabarkan diatas untuk membentuk warga negara yang baik dalam ranah pendidkan kewarganegaraan diluar sekolah. Namun berdasarkan hasil yang ditemukan dilapangan penelitian peran PKK belum dapat dilaksanakan secara baik karena komponen partispasif belum dimiliki oleh warga negara itu sendiri, sehingga berpengaruh pada pencapaian komponen intelektual dan komponen sosial.

\section{SIMPULAN DAN SARAN}

\section{Simpulan}

Keberhasilan dari pelaksanaan program pokok PKK dibidang pendidikan dan keterampilan adalah melalui partisipasi masyarakat. Selain partisipasi masyarakat, kerja sama anatara masyarakat, PKK dan pemerintah juga sangat dibutuhkan. Dengan pemberdayaan yang dilakukan pemerintah melalui PKK dalam ranah citizenship education diharapkan seluruh warga negara ikut berpartisipasi untuk menyukseskan kegiatan pemberdayaan tersebut. Karena tanpa partisipasi dari warga negara, maka seluruh proses yang ditujukan untuk membantu masyarakat memperoleh daya kuasa dalam hidup berbangsa dan bernegara serta memajukan pembangunan nasional tidak dapat berjalan.

Faktor pendukung TP.PKK dalam meningkatkan keterampilan warga negara adalah semangat masyarakat, ADD yang mendukung untuk pelaksanaan program pendidikan dan keterampilan, kesadaran masyarakat yang menyatakan tanggapan bahwa kegiatan ini sangat baik dan bagus,tempat pelaksanaan kegiatan, dan dukungan perangkat desa. Faktor pendukung menjadi modal TP.PKK untuk meningkatkan keterampilan masyarakat. Dengan adanya pelaksanaan kegiatan ini diharapkan masyarat dapat mengembangkannya lagi. Sehingga pemenuhan komponen keterampilan warganegara dalam ranah citizenship education dapat terlaksana dengan baik. 
JIP, Vol.8, No. 1, Edisi Januari 2018, Hal: 62-71

Ludovikus Bomans Wadu, Iskandar Ladamay, Maria Yosefina Dadi

Faktor penghambat TP.PKK dalam meningkatkan keterampilan warga negara adalah kesibukan dari masyarakat, pemasaran hasil kegiatan yang belum maksimal, dan keterbatasan dana yang dialami masyarakat untuk mengembangkan hal yang telah diajarkan oleh TP.PKK. Faktor penghambat diatas menjadi kendala utama bagi TP.PKK untuk meningkatkan keterampilan warga negara. Dengan adanya faktor penghambat diatas dapat dilihat peran TP.PKK untuk meningkatkan keterampilan warga negara belum dapat dilakukan secara optimal. Dengan adanya faktor penghambat ini, diharapkan masyarakat dan TP.PKK dapat bekerjasama untuk menyelesaikan faktor penghambat yang dialami sehingga pemenuhan komponen keterampilan warga negara dapat dimiliki oleh masyrakat.

\section{Saran}

Kegiatan dalam rangka membina keterampilan masyarakat melalui program pokok PKK dapat berjalan dengan baik apabila ada kerja sama dari PKK, masyarakat dan pemerintah agar faktor pendukung tetap dipertahankan dan faktor penghambat dapat diatasi. Diharapkan PKK sebagai mitra kerja pemerintah dapat menyelesaikan kendala yang dihadapi secara tepat, sehingga partisipasi masyarakat untuk mengikuti semua program PKK dapat meningkat. Karena tanpa partisipasi dari masyarakat kegiatan ini tidak dapat berjalan dengan baik. Pemerintah dan PKK sebaiknya bekerja sama untuk menyukseskan program pendidikan dan keterampilan sehinggga dapat menarik mintat masyarakat untuk berpartisipasi.

\section{DAFTAR PUSTAKA}

\section{Buku}

Creswell.(2016).Research

Design.Yogyakarta : Pustaka

Pelajar.

Moleong.(2016).Metode Penelitian

Kualitatif.Bandung : PT.Remaja

Rosdakarya.

\section{Jurnal}

Adnan.(2015).Pendidikan

Kewarganegaraan (Civic

Education) Pada Era

Demokratisasi, 4

(1).(online).(www.jurnal.fkip.uns.

ac.id), diaksses 4 Oktober 2017

Arisandi Desi.(2015).Peran PKK Di

Dalam Pemberdayaan

Perempuan Di Desa Muara

Bengkal Ilir Kecamatan Muara Bengkal Kabupaten Kutai Timur, 3 (4).(online).(ejournal.ip.fisipunmul.ac.id), diakses 4 September 2017.

Narmoatmjo Winarno.(2017).Pemikiran Aristoteles Tentang

Kewarganegaraan

Dan

$\begin{array}{lll}\text { Konstitusi. } 17 & \text { (3).(online). }\end{array}$ (https://jurnal.ugm.ac.id), $\quad 5$ September 2017.

Riana, dkk.(2014). Pelaksanaan Peran Tim Penggerak Pemberdayaan Dan Kesejahteraan Keluarga (PKK) Dalam Memberdayakan Perempuan (Studi tentang Program Pendidikan dan Keterampilan di Kecamatan Kaliori, Kabupaten Rembang). 2 
JIP, Vol.8, No. 1, Edisi Januari 2018, Hal: 62-71

Ludovikus Bomans Wadu, Iskandar Ladamay, Maria Yosefina Dadi

(5).(online).(download.portalgaru da.org/article.php), 5 September 2017.

Setiawan Deny.(2014). Pendidikan

Kewarganegaraan Berbasis

Karakter melalui Penerapan

Pendekatan Pembelajaran Aktif,

Kreatif, Efektif dan

Menyenangkan. 6 (2).(online).

(http://download.portalgaruda.org

/article.php?), diakses 7

Desember 2017.

Shalfiah Ramandita.(2013).Peran

Pemberdayaan Dan

Kesejahteraan Keluarga (PKK)

Dalam Mendukung Program -

program Pemerintah Kota

Bontang.

(3).(online).(perpustakaan.unmul.

ac.id/ejournal/index.php/um/articl

e/download/92/78), diakses 4

September 2017.

Sutiyono.(2017). Pengembangan Civics

Skills Melalui Seminar Cocrates

Dalam

Pendidikan

Kewarganegaraan.2

(2).(online).(http://journal.umpo.a

c.id/index.php/JPK/article/view/5

28/503), diakses 7 Desember 2017.

Trisnawati dan Jatiningsih.(2017).Strategi

Pemberdayaan Kesejahteraan

Keluarga (PKK) dalam

Pemberdayaan Perempuan di

Kelurahan Sukorame Kecamatan

Gresik Kabupaten Gresik, 5

(3).(online).(jurnalmahasiswa.une

sa.ac.id), diakses 7 September

2017.

\section{Website}

Keputusan Menteri Dalam Negeri Dan

Otonomi Daerah Republik

Indonesia Nomor: 53 Tahun

2000 Tentang Gerakan

Pemberdayaan Dan

Kesejahteraan KeluargaMenteri

Dalam Negeri Dan Otonomi

Daerah. (online).(www.kemendagri.go.id), diakses 19 Oktober 2017. 